\title{
BEYOND THE RHETORIC OF COMPARATIVE INTEREST BALANCING: AN ALTERNATIVE APPROACH TO EXTRATERRITORIAL DISCOVERY CONFLICTS
}

\section{INTRODUCTION}

In a tort action before a U.S. court, the Plaintiff seeks to compel the corporate Defendant to produce documents held by the Defendant's Canadian subsidiary. The Defendant counters by moving for a protective order prohibiting the discovery, arguing that a Quebec blocking statute ${ }^{1}$ prevents the disclosure of the documents. ${ }^{2}$ At stake are the conflicting interests of the Plaintiff, the Defendant, the United States, and the Canadian province of Quebec. ${ }^{3}$ Courts faced with this increasingly common type of

Copyright $\odot 1988$ by Law and Contemporary Problems

1. Blocking statutes, or nondisclosure laws, are laws that prohibit the disclosure or removal of documents located in the territory of the enacting state in compliance with orders of foreign authorities. Restatement (Revised) of Foreign Relations Law of the United States \$ 437 reporter's note 4 (1986) [hereinafter Restatement (REvised)]. Such legislation is designed to counter U.S. efforts to secure foreign production and has been enacted in several foreign states, including Australia, Belgium, Canada, Denmark, Finland, France, India, New Zealand, the Netherlands, the Philippines, South Africa, Switzerland, the United Kingdom, and West Germany. The complete texts of most of these foreign blocking statutes are reprinted in A. LowE, Extraterritorial Jurisdiction-An Annotated Collection of Legal Materials (1983).

2. This hypothetical is based on the fact situation presented in State v. Keene Corp., No. 1108600, slip op. (Cir. Ct. Md. July 10, 1986) (granting protective order). The blocking statute involved in Keene Corp. was the Quebec Business Concerns Records Act, Que. Rev. StaT. ch. D-12 (1977) [hereinafter Quebec Act].

3. The Plaintiff has an interest in having the adjudication go forward with the best evidence available. In addition to the obvious desire of avoiding the admission of potentially damaging evidence, the Defendant has an interest in avoiding the criminal sanctions (up to one year's imprisonment) which may be imposed for violating the provisions of the blocking statute. Quebec Act, supra note $2, \S 5$. The interests of the United States include the interest in protecting U.S. citizens from harmful products and compensating them for injuries resulting from the use of such products, and the interest in deciding cases on the basis of all relevant information in accord with the Federal Rules of Civil Procedure. FED. R. CIv. P. 26(b)(1). The interests of the Province of Quebec in the nondisclosure of business records located within its borders are reflected in the Quebec Act. The fact that the Quebec Act makes the removal of records from Quebec in pursuance of an order by a foreign authority a criminal offense punishable by imprisonment illustrates that the Quebec Parliament considered protection of business records to be of critical importance to a viable business environment and to the territorial integrity of the province. Quebec Act, supra note 2. 
extraterritorial jurisdictional conflict receive scant guidance from the confused and inconsistent case law and vague authoritative pronouncements on the subject of extraterritorial discovery.

Most courts ostensibly employ one of several comparative interest balancing approaches ${ }^{4}$ to determine whether production should be ordered in cases in which domestic corporations refuse to produce documents held by their foreign subsidiaries, branches, or parent corporations because of the existence of a foreign blocking statute. The term "comparative interest balancing" denotes a decisionmaking process in which the court identifies the conflicting interests of each state, weighs each state's interest against that of the other, and makes a decision according "to the turn of the scale." 5 Although each of the several comparative interest balancing approaches lists factors to be balanced, none explains how the factors are to be evaluated or how they are to be weighed against one another. ${ }^{6}$ The major weaknesses of comparative interest balancing are simply that courts lack the institutional resources and expertise to assess the interests of foreign states and that no judicially manageable standards exist for assigning weight to competing national interests. ${ }^{7}$ As a number of commentators have pointed out, balancing national interests is a political, not legal task, ${ }^{8}$ and is unlikely to produce the predictability and certainty necessary to minimize jurisdictional conflicts. $^{9}$

In recognition of these deficiencies of comparative interest balancing, this note proposes not a better rule of law, but rather a more realistic and coherent process for extraterritorial decisionmaking in cases involving

4. For a summary of judicial application of interest balancing, see RESTATEMENT (REvisED), supra note $1, \S 437$ reporter's note 7 . But see In re Uranium Antitrust Litig., 480 F. Supp. 1138,1148 (N.D. Ill. 1979).

5. Maier, Interest Balancing and Extraterritorial Jurisdiction, 31 Ам. J. CoмP. L. 579, 589 (1983).

6. See Restatement (Revised), supra note $1, \S 437(1)$ (c); Restatement (Second) of Foreign Relations Law of the United STates $\$ 40$ (1965) [hereinafter Restatement (SEcond)]; Mannington Mills, Inc. v. Congoleum Corp., 595 F.2d 1287, 1297 (3d Cir. 1979); Timberlane Lumber Co. v. Bank of Am., 549 F.2d 597, 614 (9th Cir. 1976), aff d, 749 F.2d 1378 (9th Cir. 1984).

7. These weaknesses were noted in In re Uranium Antitrust Litig., 480 F. Supp. 1139,1148 (N.D. Ill. 1979), where the court rejected the comparative interest balancing approach and concluded:

Aside from the fact that the judiciary has little expertise, or perhaps even authority, to evaluate the economic and social policies of a foreign country, . . . [i]t is simply impossible to judicially "balance" these totally contradictory and mutually negating actions.

Similar sentiments were echoed in Laker Airways v. Sabena, Belgian World Airlines, 731 F.2d 909, 949-50 (D.C. Cir. 1984), in which the D.C. Circuit Court of Appeals stated:

Given the inherent limitations of the Judiciary, which must weigh these issues in the limited context of adversarial litigation, we seriously doubt whether we could adequately chart the competing problems and priorities that inevitably define the scope of any nation's interest in a legislated remedy.

8. See Gerber, Beyond Balancing: International Law Restraints on the Reach of National Laws, 10 YALE J. INr'L L. 185, 205 (1984); Durack, Australia: Conflicts and Comity, in Act of STATE AND Extraterritorial Reach: Problems of Law and Policy 41, 44 (J. Lacey ed. 1983); Onkelinx, Conflict of International Jurisdiction: Ordering the Production of Documents in l'iolation of the Law of the Situs, 64 Nw. U.L. REv. 487, 531 (1969).

9. See Note, Predictability and Comity: Toutard Common Principles of Extratemitorial Jurisdiction, 98 HaRv. L. REv. 1310, 1322 (1985); Gerber, supra note 8. 
conflict between discovery and foreign blocking statutes. This note focuses on the distinction between interest balancing within the realm of "private law" and "public law."10 The critical difference lies in the fact that interest balancing in public law cases has operated as a means of asserting the primacy of U.S. interests" in the guise of applying a "jurisdictional rule of reason." 12 Although courts profess to apply a comparative interest balancing approach, in public law cases they actually exercise enforcement jurisdiction ${ }^{13}$ whenever more than a de minimis U.S. interest is present; consideration of foreign interests is rarely more than perfunctory. ${ }^{14}$ Only in private law cases are courts willing to defer to foreign interests. ${ }^{15}$ This note seeks to conform the courts' rhetoric to reality by providing an analytical framework which acknowledges that interest analysis has actually been, by necessity, unilateral and non-comparative.

Before setting forth the proposed approach, this note first examines the several balancing approaches that courts have attempted to follow. Next, this note exposes the deficiencies inherent in comparative interest balancing. Finally, this note describes a methodological paradigm that more accurately reflects the substance, if not the form, of judicial decisionmaking in the area of extraterritorial discovery than do comparative interest balancing formulations.

\section{Comparative Interest Balancing}

\section{A. Societe Intermationale: A Legacy of Confusion}

The United States is presently the only nation which regularly compels foreign discovery in conflict with local foreign law. ${ }^{16}$ Prior to 1958 , however, U.S. courts, like their foreign counterparts, deferred to foreign interests on a

10. As defined in this note, "private law" includes cases of a purely private civil law nature such as contract and tort actions. "Public law" refers to cases of a significant national interest such as securities, tax, patent, antitrust, and criminal proceedings.

11. See, e.g., Laker Airways v. Sabena, Belgian World Airlines, 731 F.2d 909, 950-51 (D.C. Cir. 1984).

12. Restatement (Revised), supra note $1, \S 503(1)$.

13. Enforcement jurisdiction is the power of a state "to induce or compel compliance or punish noncompliance with its laws or regulations. ..." Restatement (REvised), supra note 1, at $\$ 401$ (3). Thus, when a court in one state orders a party, under the threat of sanctions for non-compliance, to produce documents that are located in another state, it exercises enforcement jurisdiction. Id. § 431 comment b.

14. See infra notes $72-73,86-104$ and accompanying text.

15. See infra notes 105-109 and accompanying text.

16. See Rosenthal \& Yale-Loehr, Two Cheers for the ALI Restatement's Provisions on Foreign Discovery', 16 N.Y.U. J. InT'L L. \& Pol. 1075, 1075-77 (1984). See, e.g., Frischke v. Royal Bank, 17 Ont.2d 388 (1970). In Frischke, the Ontario Court of Appeals declined to order production of documents located in Panama, stating that notwithstanding exceptional circumstances, "[a]n Ontario court would not order a person here to break our laws; we should not make an order that would require someone to compel another person in that person's jurisdiction to break the laws of that state." Id. at 399. See also Lonrho Ltd. v. Shell Petroleum Co., 1 W.L.R. 627, 634-35 (H.L. 1980) (holding that the existence of a local foreign law prohibiting disclosure prevents the documents from being in a party's power for the purposes of ordering discovery). 
basis of comity ${ }^{17}$ and would not order discovery within the territory of another state when such disclosure conflicted with the law of that state. ${ }^{18}$ It was in that year that the Supreme Court, in Societe Internationale Pour Participations Industrielles et Commerciales, S.A. v. Rogers ${ }^{19}$ (Societe Internationale), upheld a production order despite the fact that disclosure of the records would violate Swiss penal laws and would lead to the imposition of criminal sanctions. ${ }^{20}$ Thus began the era of extraterritorial discovery conflict.

In Societe Internationale, a Swiss holding company brought suit against the Attorney General of the United States to recover property seized during World War II under the Trading with the Enemy Act. ${ }^{21}$ Pursuant to discovery requests, the district court ordered the plaintiff to produce certain documents relevant to the issue of plaintiff's possible enemy taint. The records were not produced on the ground that production would violate Swiss secrecy laws, which carried criminal penalties, and the district court imposed the sanction of dismissal with prejudice of plaintiff's complaint. On appeal, the Supreme Court held that the production order was justified notwithstanding the nondisclosure law, but held also that a party's failure to comply with a production order due to inability fostered neither by its own conduct nor by circumstances within its control did not justify the sanction of dismissal with prejudice. ${ }^{22}$

Societe Internationale is the only case in which the Supreme Court has directly confronted the issue of conflict between a discovery order of a U.S. court and a foreign blocking statute. Although Societe Internationale is universally recognized as holding that severe sanctions for noncompliance with a production order will be imposed only upon a showing of bad faith, courts have subsequently focused on various other aspects of the Supreme Court's decision, such as its bifurcated analysis ${ }^{23}$ and its stress on the importance of the requested documents in illuminating key elements of the claims. ${ }^{24}$ Apart from the requirement of good faith, however, the Supreme

17. Comity has been defined as "a way of saying fair play-that each of two parties will yield to the one that has interests that are clearly paramount.... Where conflicts arise between sovereigns, the sovereigns have an obligation to resolve the conflict with restraint, cooperation and good will." Durack, supra note 8, at 43 (quoting former United States Attorney General, Judge Griffin Bell).

18. See, e.g., Hirshorn v. Hirshorn, 278 A.D. 1006, 1007, 105 N.Y.S.2d 628, 630 (1951).

19. 357 U.S. $197(1958)$.

20. Id. at 205.

21. Id. at 199 .

22. Id. at 212 .

23. The Court in Societe Internationale considered the validity of discovery orders and the issue of the propriety of sanctions separately, stating: "Such reasons [for noncompliance], and the willfulness or good faith of petitioner, can hardly affect the fact of noncompliance and are relevant only to the path which the District Court might follow in dealing with petitioner's failure to comply." Id. at 208. See Arthur Anderson \& Co. v. Finesilver, 546 F.2d 338, 341 (10th Cir. 1976), cert. denied, 429 U.S. 1096 (1976) ("Societe implies that consideration of foreign law problems in a discovery context is required in dealing with sanctions to be imposed for disobedience and not in deciding whether the discovery order should issue"). But see SEC v. Banca Della Svizzera Italiana, 92 F.R.D. 111,117 n.3 (S.D.N.Y. 1981) (noting that the Second Circuit, unlike other circuits, does not distinguish the analysis used for deciding to issue an order compelling discovery from that used for imposing sanctions).

24. See, e.g., In re Uranium Antitrust Litig., 480 F. Supp. 1138, 1146 (N.D. Ill. 1979). 
Court's analysis of the validity of the discovery order is masked in ambiguity. As a result, the decision has produced more confusion than guidance. ${ }^{25}$

Much of the confusion surrounding the proper interpretation of Societe Internationale stems from a passage in the decision in which the Court stated:

We do not say that this ruling would apply to every situation where a party is restricted by law from producing documents over which it is otherwise shown to have control. Rule 34-of the Federal Rules of Civil Procedure-is sufficiently flexible to be adapted to the exigencies of particular litigation. The propriety of the use to which it is put depends upon the circumstances of a given case, and we hold only that accommodation of the Rule in this instance to the policies underlying the Trading with the Enemy Act justified the action of the District Court in issuing this production order. ${ }^{26}$

Many courts and commentators have interpreted this language as calling for "a balancing approach on a case-by-case basis."27 One court has nevertheless noted that "the Court gave no hint that the disclosure policies of the American statute should be balanced against the secrecy policies of the Swiss law," and concluded instead that "the only pertinent inquiry is the strength of the American interests." 28 It is more likely that the Court never even considered, let alone decided, the issue of whether interest balancing is required. A review of the briefs submitted by the parties in Societe Internationale reveals that the issue of whether the courts below impermissibly failed to balance interests before ordering production was never raised. ${ }^{29}$

\section{B. The Approach of the Restatements: Factors Without Guidance}

For many courts, the question of the proper interpretation of Societe Internationale was resolved by the American Law Institute when it published the Restatement (Second) of Foreign Relations Law of the United States in 1965. ${ }^{30}$ The prestige of the American Law Institute and of the drafters of the Restatement (Second) quickly established the Restatement as a leading authority in cases involving extraterritorial discovery conflicts. ${ }^{31}$ The Restatement (Second) took on enhanced significance because of the confusion created by Societe Internationale and the fact that American judges are generally not as familiar with international law as with domestic law.

The Restatement (Second) does not directly address the problem of extraterritorial discovery conflicts. Instead, it contains a general section

25. For a discussion of the numerous conflicting judicial approaches spawned by Societe Internationale, see Browne, Extraterritorial Discovery: An Analysis Based on Good Faith, 83 Colum. L. REv. $1320,1324-39(1983)$.

26. 357 U.S. $197,205-06(1958)$.

27. See, e.g., In re Westinghouse Electronic Corp. Uranium Contracts Litig., 563 F.2d 992, 997 (10th Cir. 1977).

28. In re Uranium Antitrust Litig., 480 F. Supp. 1138, 1146 (N.D. Ill. 1979).

29. Brief of the Government of the United Kingdom of Great Britain and Northern Ireland as Amicus Curiae in Support of Petitioners at $8 \mathrm{n.9}$, Societe Nationale Industrielle Aerospatiale v. United States Dist. Ct., 107 S. Ct. 2542 (1987).

30. Although this was actually the American Law Institute's first Restatement of United States Foreign Relations Law, it was entitled the "Restatement (Second)" because it was published with a second wave of other restatement volumes. Rosenthal \& Yale-Loehr, supra note 16, at 1082 n.28.

31. Id. at 1082 . 
pertaining to international jurisdictional conflicts. This provision declares that states are required by international law to moderate their exercise of jurisdiction by weighing all respective interests. ${ }^{32}$ The Restatement (Second) lists five factors to be balanced, including the vital national interests of each of the states. ${ }^{33}$ The Restatement (Second), however, mentions nothing about how these factors are to be ascertained or evaluated, and provides no standards by which the factors may be weighed against each other.

In May 1986, the American Law Institute approved the Restatement (Revised) of Foreign Relations Law which employs the same type of comparative interest balancing formulation as the Restatement (Second). ${ }^{34}$ The Restatement (Revised), however, elevates the balancing test from a doctrine of comity to a criterion of jurisdiction vel non (literally meaning jurisdiction or not). In contrast to the Restatement (Second), the Restatement (Revised) requires comparative interest balancing "not as a basis for requiring that states consider moderating their enforcement of laws which they are authorized to prescribe, but as an essential element in determining whether, as a matter of international law, the state has jurisdiction to prescribe" the laws at all. ${ }^{35}$

Although the Restatement (Revised) is in some respects a substantial improvement over the Restatement (Second), ${ }^{36}$ its balancing formula is no less vague than that of its predecessor. A comment following its text indicates

32. Restatement (SECOND), supra note 6, § 40 states:

Where two states have jurisdiction to prescribe and enforce rules of law and the rules they may prescribe require inconsistent conduct upon the part of a person, each state is required by incernational law to consider, in good faith, moderating the exercise of its enforcement jurisdiction, in the light of such factors as

(a) vital national interests of each of the states,

(b) the extent and the nature of the hardship that inconsistent enforcement actions would impose upon the person,

(c) the extent to which the required conduct is to take place in the territory of the other state,

(d) the nationality of the person, and

(e) the extent to which enforcement by actions of either state can reasonably be expected to achieve compliance with the rule prescribed by the state.

33. Id. \& 40(a).

34. Restatement (Revised), supra note 1, $\$ 437(1)$ (c) states:

In issuing an order directing production of information located abroad, a court or agency in the United States should take into account the importance to the investigation or litigation of the documents or other information requested; the degree of specificity of the request; whether the information originated in the United States; the availability of alternative means of securing the information; and the extent to which noncompliance with the request would undermine important interests of the United States, or compliance with the request would undermine important interests of the state where the information is located.

The comment to this section indicates that in addition to these factors, the eight factors listed in $\S 403$ of the Restatement (Revised) should also be considered. Id. $\$ 437$ comment $\mathrm{c}$.

35. Id. $\$ 403$ reporter's note 10 . Contrary to the assertion of the American Law Institute, however, one court has noted that "there is no evidence that interest balancing represents a rule of international law." Laker Airways v. Sabena, Belgian World Airlines, 731 F.2d 909, 950 (D.C. Cir. 1984).

36. Unlike the Restatement (Second), the Restatement (Revised) explicitly adopts various aspects of the Societe Internationale analysis, such as the requirement of a stringent standard of relevance and the bad faith prerequisite to the imposition of severe sanctions. Restatement (REviSED), supra note $1, \S 437(2)$ b \& comment a. 
that the Restatement (Revised)'s list of factors to be balanced is not meant to be exhaustive and acknowledges that "no special significance or scheme of priorities is implied in the order in which the factors are listed. Not all factors are equally important in all situations, and the weight to be given to any particular factor or group of factors will depend on the circumstances."37

An impressive number of courts have professed to follow the approach of the two Restatements of Foreign Relations Law, ${ }^{38}$ yet attempts to apply their hollow balancing formulas have resulted largely in confused, ad hoc decisionmaking. ${ }^{39}$ Judicial refinement and expansion of the list of factors to be balanced 40 have not added coherence or certainty to the balancing calculus. Lacking a conceptual structure and an assessable metric for weighing relative interests, the balancing approach of the Restatements has failed to provide a basis for developing predictability over time.

\section{Aerospatiale: An Opportunity for Clarification Squandered}

Despite confused and inconsistent judicial application of the Restatement's vague balancing formula, the Supreme Court has, since its 1958 holding in Societe Internationale, consistently declined to render additional guidance on the issue of extraterritorial discovery conflicts. ${ }^{4}$ The Court's latest refusal to clarify the criteria that U.S. courts should employ in determining when to require production of evidence located abroad in contravention of foreign blocking statutes came in 1987 with its decision in Societe Nationale Industrielle Aerospatiale v. United States District Court for the Dist. of Iowa. ${ }^{42}$

The Aerospatiale case arose out of a products liability suit against French aircraft manufacturers. When the U.S. plaintiffs sought broad discovery of evidence located abroad under the Federal Rules of Civil Procedure, the foreign defendants moved for a protective order, arguing that the U.S. court should prohibit discovery in France through any procedures other than those provided in the Hague Evidence Convention. Because article 23 of the Hague Convention provides that contracting states may declare that they will refuse

37. Id. $\$ 403$ comment b.

38. Id. $\$ 437$ reporter's note 7 (listing cases that have followed the Restatement (Second) balancing approach. For cases citing the tentative drafts of the Restatement (Revised), see Graco v. Kremlin, Inc., 101 F.R.D. 503, 509 (N.D. Ill. 1984); United States v. First Nat'l Bank of Chicago, 699 F.2d 341, 346 (7th Cir. 1983); United States v. Toyota Motor Corp., 569 F. Supp. 1158, 1162 (C.D. Cal. 1983).

39. For a discussion of the confused judicial application of the Restatement balancing formula, see Browne, supra note 25, at 1330-39.

40. See Mannington Mills, Inc. v. Congoleum Corp., 595 F.2d 1287, 1297 (3d Cir. 1979); Timberlane Lumber Co. v. Bank of Am., 549 F.2d 597, 614 (9th Cir. 1976), aff $d$, 749 F.2d 1378 (9th Cir. 1984). For an analysis of the Timberlane approach, see Maier, Extraterritorial Jurisdiction at a Crossroads: An Intersection Between Public and Private International Law, 76 AM. J. INT'L L. 280, 296-300 (1982).

41. The Supreme Court declined to grant certiorari in a case raising the issue most recently in $I / \prime$ re Grand Jury Proceedings Bank of Nova Scotia, 740 F.2d 817 (1l th Cir. 1984), cert. demied, 469 U.S. $1106(1985)$.

42. 107 S. Ct. 2542 (1987). 
requests for the type of sweeping pre-trial discovery known in common law countries, ${ }^{43}$ application of the Convention can potentially have an effect identical to imposition of a blocking statute. ${ }^{44}$ Therefore, despite the fact that the case involved application of the Hague Convention rather than conflict with an actual blocking statute, it nonetheless presented an ideal opportunity for the Court to refine the formula for resolving all extraterritorial discovery conflicts.

Citing the comparative interest balancing formula of section 437 of the Revised Restatement of Foreign Relations Law, the Supreme Court held that the Hague Convention's procedures constitute an option that a U.S. court may or may not elect to employ, depending on the outcome of "scrutiny in each case of the particular facts [and] sovereign interests." 45 The Court, however, evaded the underlying issue of exactly how the comparative interest balancing approach is to be applied by stating " $[\mathrm{w}] \mathrm{e}$ do not articulate specific rules to guide this delicate task of adjudication." 46

The majority's holding produced a sharply worded dissent in which Justice Blackmun, joined by Justices Brennan, Marshall, and O'Connor, exclaimed that "[e]xperience to date indicates that there is a large risk that the case-bycase comity analysis now to be permitted by the Court will be performed inadequately."47 Arguing that the Court should have instead adopted a general presumption that courts should resort first to the procedures of the Hague Convention, Justice Blackmun stated, "I dissent because I cannot endorse the Court's case-by-case inquiry . . . and its failure to provide lower courts with any meaningful guidance for carrying out that inquiry."48 $\mathrm{He}$ concluded that, "[ $t]$ he majority fails to offer guidance in this endeavor, and thus it has missed its opportunity to provide predictable and effective procedures for international litigants in United States courts." 49

If the legacy of Societe Internationale can be said to be confusion, the Court's latest decision involving extraterritorial discovery conflicts will be remembered as a missed opportunity to resolve that confusion. Although the majority in Aerospatiale refrained from explicitly stating how its decision would affect lower court cases involving foreign blocking statutes, it is likely that the Aerospatiale precedent will be interpreted as endorsing a vague notion of comparative interest balancing in that context as well.

43. 23 U.S.T. at 2568 , TIAS 7444. Thirteen of the seventeen signatory states have made such declarations under Article 23 of the Convention. See 7 Martindale-Hubbell Law Directory 15-19 (1986).

44. See S\&S Screw Mach. Co. v. Cosa Corp., 647 F. Supp. 600, 617 (M.D. Tenn. 1986) (granting protective order in contract case in which, pursuant to article 23 of the Hague Convention, West Germany refused American pre-trial discovery requests).

45. Aerospatiale, 107 S. Ct. at 2555-56..

46. $107 \mathrm{~S}$. Ct. at 2557.

47. $107 \mathrm{~S}$. Ct. at 2558. The dissent later elaborated that "courts are generally ill-equipped to assume the role of balancing the interests of foreign nations with that of our own [and that a] proforum bias is likely to creep into the supposedly neutral balancing process." $107 \mathrm{~S}$. Ct. 2560.

48. $107 \mathrm{~S}$. Ct. at 2558.

49. 107 S. Ct. at 2568. 


\section{The Deficiencies of Comparative Interest Balancing}

Vagueness is but one of the many deficiencies inherent in comparative interest balancing which render it an impractical approach to the problem of extraterritorial discovery conflicts. A second major problem with comparative interest balancing is that courts are simply unable to ascertain and to evaluate accurately the interests of the foreign states that are to be weighed against those of the United States. The Restatement (Second) requires an assessment of the "vital national interests" of the foreign state, 50 and the Restatement (Revised) calls for an inquiry as to "the extent to which compliance with an order to produce the requested information would affect important substantive policies or interests of the state." 51 Yet, unlike the United States Department of State, the judiciary possesses neither the special training nor the resources necessary to analyze the economic, political, and social interests that underlie a foreign state's policies of nondisclosure. Several courts have acknowledged that the judiciary lacks the "institutional resources,"52 the expertise, and perhaps even the authority 53 to "adequately chart the competing problems and priorities that inevitably define the scope of any nation's interest in a legislated remedy." 54

The Act of State doctrine presents a further barrier to the evaluation of the foreign interests underlying blocking legislation. The doctrine, which prevents an American court from sitting in judgment of the public acts of another country, ${ }^{55}$ directly conflicts with the position taken by the Restatement (Revised) that foreign "statutes that frustrate [discovery] need not be given the same deference by courts of the United States as substantive rules of law at variance with the law of the United States." 56 One court has recently rejected this assertion by the Restatement (Revised), noting that it is "somewhat presumptuous, to gauge the importance of the Blocking Statute to France." 57 This view was also highlighted in recent litigation in which the United Kingdom stated that it is as politically intolerable for leaders of foreign democracies to have their official policies evaluated, balanced, and coerced by

\footnotetext{
50. Restatement (SEcond), supra note 6, \$40(a).

51. Restatement (Revised), supra note 1, \$437 comment c.

52. Laker Airways v. Sabena, Belgian World Airlines, 731 F.2d 909, 955 (D.C. Cir. 1984).

53. In re Uranium Antitrust Litig., 480 F. Supp. 1138, 1148 (N.D. Ill. 1979).

54. Laker Airways v. Sabena, Belgian World Airlines, 731 F.2d 909, 950 (D.C. Cir. 1984).

55. The doctrine was first promulgated in Underhill v. Hernandez, 168 U.S. 250, 252 (1897), where the Supreme Court declared:
}

Every sovereign State is bound to respect the independence of every other sovereign State, and the courts of one country will not sit in judgment of the acts of the government of another done within its own territory.

For a recent example of the doctrine's application, see Int'l Ass'n of Machinists \& Aerospace Workers v. OPEC, 649 F.2d 1354 (9th Cir. 1981), in which the court held that even where no sovereign state is a party to the action, the Act of State doctrine prevents a federal court from questioning the propriety of sovereign acts of foreign states such as the price setting activities of OPEC states.

56. Restatement (REvised), supra note $1, \S 437$ reporter's note 5 .

57. Graco v. Kremlin, Inc., 101 F.R.D. 503, 513 (N.D. Ill. 1984). 
U.S. courts as it would be for American leaders to have important U.S. policies and interests evaluated, judged, and coerced in foreign courts. ${ }^{58}$

Even assuming domestic courts have the ability and authority to gauge vital foreign interests, they cannot reliably and impartially balance the foreign interests against those of the United States. In Laker Airways v. Sabena, Belgian World Airlines, ${ }^{59}$ Judge Malcolm Wilkey of the D.C. Circuit Court of Appeals argued that domestic courts are incapable of sitting as international tribunals and evenhandedly balancing national interests. He concluded that "courts inherently find it difficult neutrally to balance competing foreign interests." 60 Given the vagueness of existing comparative interest balancing approaches, it is small wonder that a court might be encouraged to assert the primacy of U.S. interests. A court is likely to have difficulty, especially in a case involving U.S. nationals, in denying jurisdiction, unless it can base its decision on a concrete legal principle that clearly prohibits the exercise of such jurisdiction. ${ }^{61}$ Comparative interest balancing provides no such concrete principle.

Finally, judicial use of comparative interest balancing is contrary to the political question doctrine which removes certain issues from the scope of judicial review. ${ }^{62}$ In Baker $v$. Carr,${ }^{63}$ the Supreme Court extensively reviewed the history and evolution of the political question doctrine and explained that when the resolution of questions touching foreign relations turns on standards that defy judicial application, or involves the exercise of discretion demonstrably committed to the executive or legislature, such questions are nonjusticiable political questions. ${ }^{64}$ The preceding discussion has illustrated that comparative interest balancing incorporates "purely political factors which the court is neither qualified to evaluate comparatively nor capable of properly balancing." 65 In his address to the American Bar Association in August 1981, the Attorney General of Australia, Senator Peter Durack, explained:

In my view, however, it is not feasible for a court of law applying judicial techniques to balance the disparate interests of two States which they claim to be of national importance....

58. Joint Brief of United Kingdom and Cayman Islands at 16-20, In re Grand Jury Proceedings (United States v. Bank of Nova Scotia), No. 83-1 (S.D. Fla. filed Feb. 28, 1984), cited in Rosenthal \& Yeal-Loehr, supra note 16, at 1080.

59. 731 F.2d 909 (D.C. Cir. 1984).

60. Id. at $950-51$.

61. Gerber, supra note 8, at 209.

62. See generally L. Henkin, Foreign Affairs and the Constitution 208-16 (1972). The political question doctrine, which prevents judicial determination of political questions for which courts lack competence, is to be contrasted with the Act of State doctrine, which is based on "the lack of consent by foreign states to review of their actions by domestic courts of another state." RESTATEMENT (REvise.D), supra note $1, \S 428$ reporter's note 1 .

63. 369 U.S. 186 (1962).

64. Id. at 211,217. Although Baker involved the issue of legislative reapportionment, its criteria have subsequently been employed by countless courts identifying nonjusticiable political questions in cases involving foreign relations. See, e.g., Cranston v. Reagan, 611 F. Supp. 247, 252 (D.D.C. 1985), and cases cited therein.

65. Laker Airways v. Sabena, Belgian World Airlines, 731 F.2d 909, 949 (D.C. Cir. 1984). 
[I] $\mathrm{t}$ is not merely that the courts lack the expertise. It is rather that it is not part of the judicial function to decide whether a law or policy is justified by what a court conceives to be in the national interest. That is a political function. ${ }^{6 i}$

Appraisal of the national interests of a foreign state is therefore more appropriately a political rather than a judicial judgment. In accordance with the political question doctrine, a court should refrain from subscribing to a formulation whose standards are neither judicially discoverable nor manageable.

\section{III}

\section{Proposal}

Given the deficiencies inherent in comparative interest balancing, it is not surprising that the analyses of the courts in cases involving discovery orders and foreign nondisclosure laws have been inconsistent and confused. To resolve the current confusion, and to simplify the task confronting a judge or attorney in such cases, this note proposes a new framework in which to examine the factors traditionally analyzed. In contrast to previous approaches, this proposal does not require an assessment or balancing of foreign interests. Rather, it requires a straightforward and unilateral evaluation of domestic interests at the production stage of a trial.

Simply stated, under this proposal a court should issue an order for discovery upon a finding that the requested information is directly relevant and upon a further finding of any one of the following: (1) that the case involves public rather than private law; (2) that the blocking statute is not an actual barrier to production; or (3) that no reasonable good faith effort to obtain the documents was made. Accordingly, a court should refrain from ordering production, or issue a protective order preventing production, upon a finding that the requested information is not directly relevant or a finding of all of the following: (1) that the case involves private law; (2) that the blocking statute presents an actual barrier to production; and (3) that a reasonable good faith effort to obtain the documents was made. This formulation is expressed as follows:

66. Durack, supra note 8 , at 48 . 


\section{COURT SHOULD ORDER PRODUCTION}

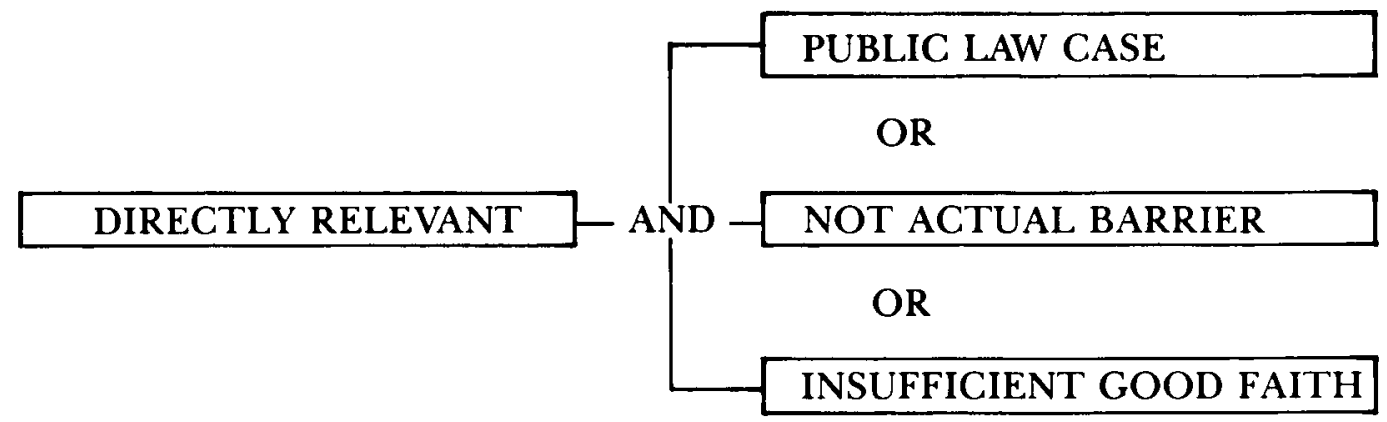

COURT SHOULD NOT ORDER PRODUCTION

NOT DIRECTLY RELEVANT OR

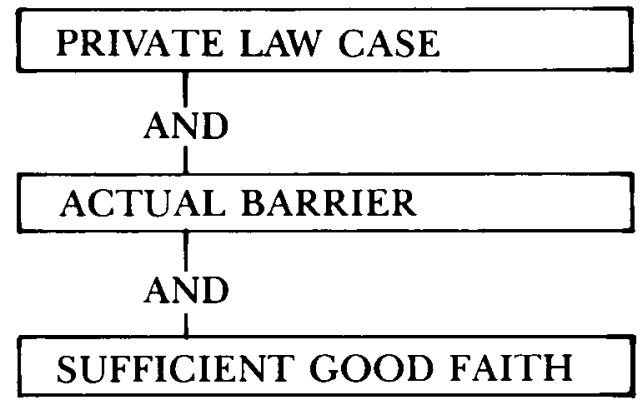

This proposed approach is not incompatible with those of the Restatements of Foreign Relations Law and Societe Internationale, but rather serves to supplement them. Although seldom expressly acknowledged, the proposed framework is in fact reflected in the substance of the case law. The following discussion examines each element of the proposed formulation, explains its rationale, and illustrates its application. Like the Reporters' Notes which explain further the text and comments of the Restatements, the ensuing discussion is meant to serve as a guide to construing and utilizing the proposed approach.

\section{A. Stringent Relevancy}

The proposed approach embraces a threshold requirement that the information requested meet a stringent standard of relevance. This requirement recognizes that courts have uniformly refused to order the production of information located in a foreign state when the information was not directly relevant, material, and necessary to the case. The rationale behind this requirement is based on the fact that the United States is the only nation which permits domestic discovery not only of clearly relevant material, but also of information which would be inadmissible at trial yet appears 
reasonably calculated to lead to the discovery of admissible evidence. ${ }^{67}$ As one court explained:

Because [U.S.] courts "are not shackled with strict interpretations of relevancy" . . discovery is permitted as to matters that "are or may become relevant," or "might conceivably have a bearing" on the subject matter of the action, or where there is "any possibility" or "some possibility" that the matters inquired into will contain relevant information. 68

Foreign states condemn such sweeping and burdensome discovery as "fishing expeditions." 69 The fishing expedition it seems, whatever its arguable merits at home, is unacceptable in international waters. ${ }^{70}$

The goal of domestic discovery in the United States is to leave no possibly relevant stone unturned. This policy differs from that of every other legal system, where each side is denied such sweeping access to the other's documents. In foreign states a party may review only those documents belonging to the other side that it can expect to enter into evidence-those having a direct and material bearing on the claims or defenses. ${ }^{71}$ Because foreign states, their courts, and their citizens have little experience with the burdens associated with the type of discovery employed in the United States, a request for foreign discovery should be very specific.

There has been judicial debate over whether Societe Internationale stands for the proposition that American courts must apply a stringent standard of relevance in cases of extraterritorial discovery. ${ }^{72}$ Moreover, the text of the Restatement (Revised) merely lists "the importance to the investigation or litigation of the ... information requested" as one of the several factors that a court should "take into account,"73 while a Reporter's note asserts that the Restatement (Revised) actually requires "a higher standard [of relevance] than applies in routine domestic cases."74 Nowhere in the Restatement (Revised), however, is such a higher standard defined. The case law, in contrast, is far less ambiguous. In the context of both public law and private

67. FED. R. Civ. P. 26(b)(1).

68. United Nuclear Corp. v. General Atomic Co., 96 N.M. 155, 174, 629 P.2d 231, 250 (1980), cert. denied, 451 U.S. 901 (1981).

69. In justifying the imposition of the Ontario blocking statute, the Prime Minister of Ontario stated: "This Government objects very strongly to fishing expeditions through our own Courts, and it is certainly not prepared to approve of fishing expeditions of this nature into the affairs of our companies through the Courts of the United States in regard to something which is not properly before those Courts." International Law Ass'n, Report of the Fifty-First Conference 567 (1964).

70. Brewster, Problems of Discovery Abroad, in ACT of State and Extraterritorial Reach: Problems of Law and Policy 66, 69 (J. Lacey ed. 1983).

71. D. Rosenthal \& W. Knighton, National Laws and International Commerce: The Problem of Extraterritoriality 70 (1983).

72. Compare In re Uranium Antitrust Litig., 480 F. Supp. 1138,1146 (N.D. Ill. 1979) ("The Court [in Societe Internationale] . . . suggested that the normal discovery standard of whether a document is relevant or is calcualted to lead to the discovery of admissible evidence does not apply, and should be replaced by the higher standard of whether the requested documents are crucial to the resolution of a key issue ... .") with Graco v. Kremlin, Inc., 101 F.R.D. 503, 515 (N.D. Ill. 1984) ("These cases do not suggest ... that the discovery requests must meet some exceptionally high standard of relevance; these cases merely indicate that the importance of the documents is a factor to be considered by the court.").

73. Restatement (Revised), supra note 1, $\$ 437(1)(\mathrm{c})$.

74. Id. $\$ 437$ reporter's note 2 . 
law cases, courts uniformly refuse to order production when the requested information is merely cumulative of available information ${ }^{75}$ or nonessential to the outcome of the case. ${ }^{76}$

\section{B. The Public Law/Private Law Distinction}

Although numerous courts have outwardly employed the balancing approach of the two Restatements, true comparative interest balancing has not been undertaken but has instead been converted de facto into a unilateral assessment of the strength of the U.S. interest in production of the documents. The approach of the Restatement (Second) and Restatement (Revised) calls first for an inquiry as to whether "vital"77 or "important"78 U.S. interests are at stake and second, for a balancing of those interests against the interests of the foreign state. ${ }^{79}$ Because the courts are unable to undertake successfully the second stage of the evaluation, the decisions turn instead solely on whether sufficient U.S. interests are involved. As Judge Wilkey explained in Laker Airways, ${ }^{80}$ "[a] pragmatic assessment of those decisions adopting an interest balancing approach indicates none where United States jurisdiction was declined when there was more than a de minimis United States interest." 81

As mentioned earlier, it is not clear whether the Supreme Court, in Societe Internationale, meant to advocate an approach based on comparative interest balancing or one based on a unilateral interest evaluation. ${ }^{82}$ Although the Court explicitly based its ruling on the fact that vital national policies were involved, ${ }^{83}$ it is uncertain whether the Court believed that the strength of the American interests concerned was the only pertinent inquiry. ${ }^{84}$ Nevertheless, Societe Internationale has been characterized by one court as holding "that a court should generally order production to effectuate strong Congressional policies." 85 On the surface, most courts have neither agreed with this interpretation of Societe Internationale nor openly acknowledged engaging in a unilateral interest evaluation. A look beyond form to substance, however, indicates that the courts' interest analyses have actually been unilateral and non-comparative.

75. See, e.g., State v. Keene Corp., No. 1108600, slip op. at 3 (Cir. Ct. Md. July 10, 1986) (declining to order production in a tort case in which the evidence was "merely cumulative").

76. See, e.g., Graco v. Kremlin, Inc., 101 F.R.D. 503, 515-16 (N.D. Ill. 1984) (declining to order production in a patent infringement suit of those documents characterized by party opposing discovery as "not vital or crucial to the resolution of a key issue in the litigation . . ."); Trade Dev. Bank v. Continental Ins. Co., 469 F.2d 35, $40-41$ (2d Cir. 1972) (declining to order production in a contract case in which the information requested "was not essential to the issue on (rial").

77. Restatement (Second), supra note $6, \S 40$ comment b.

78. Restatement (Revised), supra note $1, \S 437(1)$ (c).

79. See supra notes 32,34 .

80. Laker Airways v. Sabena, Belgian World Airlines, 731 F.2d 909, 950-51 (D.C. Cir. 1984).

81. Id. at 951

82. See supra notes $26-29$ and accompanying text.

83. Societe Internationale, 357 U.S. 197,206 (1958)

84. See supra notes $28-29$ and accompanying text.

85. In re Uranium Antitrust Litig., 480 F. Supp. 1138,1146 (N.D. Ill. 1979). 
An examination of the case law indicates that a bright line has in fact been drawn between those interests deemed vital and those recognized as insufficient to warrant a production order when disclosure is prohibited by foreign law. The Restatement (Second) defined vital national interest as "an interest such as national security or general welfare to which a state attaches overriding importance." 86 A former State Department legal advisor has explained that securities, tax, and antitrust laws are of the type which reflect important national interests which Congress has chosen to promote and to protect. ${ }^{87}$ Although the Restatement (Revised) suggests that "[i]n making the necessary determination of the interests of the United States" the court should "invite the U.S. attorney or other appropriate official to advise it of the interests of the U.S. government," 88 few courts have taken this route. Instead, the courts have simply drawn a distinction between cases involving public law (securities, ${ }^{89}$ tax,${ }^{90}$ and other criminal proceedings ${ }^{91}$ ), including quasi-public law (patent ${ }^{92}$ and antitrust actions ${ }^{93}$ ), and those involving purely private civil law (contract ${ }^{94}$ and tort claims ${ }^{95}$ ). A review of the case law further indicates that it is only in private law cases that courts have been willing to defer to foreign interests. ${ }^{96}$

A close examination of several public law and private law cases involving discovery and foreign blocking statutes clearly illustrates the distinction. For example, while purporting to follow the balancing approach of the Restatement (Second), the Eleventh Circuit, in In re Grand Jury Proceedings, ${ }^{\mathbf{9 7}}$ made no attempt whatsoever actually to evaluate or to balance the interests of the Bahamas in its bank secrecy laws. Rather, the Eleventh Circuit simply asserted that the interest of the United States in upholding the grand jury's power to investigate crime automatically outweighed the interests of the Bahamas. 98 After noting the "vital role the grand jury plays in our system of jurisprudence," 99 the court concluded that it "simply cannot acquiesce in the

86. Restatement (Second), supra note $6, \S 40$ comment b.

87. See Robinson, The Stale Department View, in ACT of State and Extraterritorial REaCh: Problems of Law and Policy 58 (J. Lacey ed. 1983).

88. Restatement (Revised), supra note 1 , $\$ 437$ comment c.

89. See, e.g., SEC v. Banca Della Svizzera Italiana, 92 F.R.D. 111,117 (S.D.N.Y. 1981).

90. See, e.g., United States v. Vetco, Inc., 691 F.2d 1281, 1289 (9th Cir.), cert. denied, 454 U.S. $1098(1981)$.

91. See, e.g., In re Grand Jury Proceedings, 691 F.2d 1384, 1387 (1 I th Cir. 1982), cert. denied, 462 U.S. 1119 (1983).

92. See, e.g., Graco v. Kremlin, Inc., 101 F.R.D. 503, $512-13$ (N.D. Ill. 1984).

93. See, e.g., In re Uranium Antitrust Litig., 480 F. Supp. 1138,1154 (N.D. Ill. 1979).

94. See, e.g., In re Westinghouse Elec. Corp. Uranium Contracts Litig., 563 F.2d 992, 999 (10th Cir. 1977).

95. See, e.g., Volkswagenwerk Aktiengesellschaft v. Superior Ct., 123 Cal. App. 3d 840,857, 176 Cal. Rptr. 874, 884 (1981).

96. D. Rosenthal \& W. Knighton, supra note 71 , at 86.

97. 691 F.2d 1384 (11 th Cir, 1982), cert. denied, 462 U.S. 1119 (1983) (holding bank in civil contempt for failing to comply with a production order in a criminal tax and narcotics investigation despite the existence of foreign bank secrecy laws).

98. Id. at 1391.

99. Id. at 1387. 
proposition that United States criminal investigations must be thwarted whenever there is conflict with the interest of other states."100

Similarly, in United States $v$. Vetco, Inc., ${ }^{101}$ the Ninth Circuit relied on the Restatement (Second) in reaching its holding that the strong U.S. interest in collecting taxes and prosecuting tax fraud by its nationals outweighed any interest Switzerland might have in preserving business secrets of Swiss subsidiaries of American corporations. Following a pattern similar to that of the Eleventh Circuit in In re Grand Jury Proceedings, the Ninth Circuit stated that "[ $\mathrm{t}]$ here is a strong American interest in collecting taxes from and prosecuting tax fraud by its own nationals operating through foreign subsidiaries." 102 After a cursory discussion of Swiss interests, the court concluded that "the United States has a powerful interest in obtaining the summoned documents, and that Switzerland has a small interest in insisting that they not be produced." 103 The Ninth Circuit specifically noted, however, that it might not have enforced the summons nor imposed sanctions if this had been a case involving private, rather than public, law. ${ }^{104}$

Although brought by private litigants and not by the government, courts have determined that patent and antitrust cases fall within the category of cases involving vital U.S. interests which automatically tip the balance in favor of compelling discovery. In the patent case of Graco v. Kremlin, Inc. ${ }^{105}$ for example, the court stated that U.S. interests of a constitutional magnitude were implicated. ${ }^{106}$ The court noted further that "U.S. patent laws rely heavily for their enforcement on private infringement actions by patent holders, and pre-trial discovery, under the Federal Rules of Civil Procedure, is an important part of the system of patent enforcement."107 Although purporting to follow the Restatement (Second)'s balancing approach, the court in Graco declined to gauge the importance of the blocking statute to France. ${ }^{108}$ Instead, it concluded that "inadequate discovery frustrates the

\footnotetext{
100. Id. at 1391 .

101. 691 F.2d 1281 (9th Cir.), cert. denied, 454 U.S. 1098 (1981).

102. Id. at 1289 .

103. Id. at 1291. But see United States v. First Nat'l Bank of Chicago, 699 F.2d 34l (7th Cir. 1983) (balancing the interests of the United States in tax collection against the interests of Greece in its bank secrecy laws, court declined to enforce an IRS summons directed to production of records maintained at the bank's Athens branch).
}

104. In explaining the distinction between public law cases and private civil law cases, the Ninth Circuit stated: "[T]he instant case turns upon an IRS summons issued pursuant to an investigation of potentially criminal conduct. Such summonses appear to serve a more pressing national function than civil discovery." 691 F.2d at 1288 . A U.S. district court reached a similar conclusion in United States v. Toyota Motor Corp., in which the court stated: "[T]he fact that this action was brought by the government, rather than a private litigant, weighs heavily towards finding a strong American interest in obtaining the information sought." 569 F. Supp. 1158, 1162-63 (C.D. Cal. 1983) (case involving tax fraud).

105. Graco v. Kremlin, Inc., 101 F.R.D. 503 (N.D. Ill. 1984). $8)$.

106. Id. at 512 (United States patent laws enacted by Congress under U.S. ConsT. art. I, $\$ 8, \mathrm{cl}$.

107. Id. at 513.

108. Id. 
purposes of the patent laws and the Constitution," 109 and ordered production of the documents which were directly relevant to the case.

In antitrust cases, courts have employed an analysis similar to that in Graco to justify compelling discovery in spite of possible competing foreign interests. In evaluating the strength of the U.S. interests at issue, one court stated: "These laws have long been considered cornerstones of this nation's economic policies, have been vigorously enforced and have been the subject of frequent interpretations by our Supreme Court."110 Another court declared that antitrust cases "are as important to the preservation of our freeenterprise system as the Bill of Rights is to the protection of our fundamental personal freedoms." 111 In the case of In re Uranium Antitrust Litigation, 112 the court received an amicus curiae brief from the Government of Canada which urged the court to defer to the "critical importance" which Canada attaches to the policies behind its blocking statute. ${ }^{13}$ The court declined to do so and instead granted an order compelling production, stating: "we would be hard pressed not to accede to the strong national policy of this country to enforce vigorously its antitrust laws."114

In contrast to these public law cases, cases involving tort or contract claims display less reluctance on the part of courts to defer to foreign interests. For example, in In re Westinghouse Electric Corp. Uranium Contracts Litigation, ${ }^{15}$ the Tenth Circuit reversed a district court order which imposed sanctions on a corporate defendant for failing to produce documents located in its Canadian office which were relevant to a claim based on contract law. In reaching its decision to defer to the interests of Canada, the Tenth Circuit explicitly recognized that its decision turned on the fact that the case involved a purely private civil law claim rather than a criminal investigation or antitrust action. ${ }^{16}$ Similarly, in an action for personal injuries against a West German automobile manufacturer, a California Court of Appeals directed the trial court to set aside an order compelling discovery of documents located in Germany. ${ }^{117}$ The court found the interests of Germany to prevail and stated

109. Id.

110. United States v. First Nat'l City Bank, 396 F.2d 897, 903 (2d Cir. 1968).

111. In re Uranium Antitrust Litig., 480 F. Supp. 1138, 1154 (N.D. Ill. 1979) (citing United States v. Topco Assocs., 405 U.S. 596, 610 (1972)).

112. 480 F. Supp. 1138 (N.D. Ill. 1979).

113. Id. at 1149 .

114. Id.

115. 563 F.2d 992 (10th Cir. 1977).

116. Id. at 999. See also S\&S Screw Machine Co. v. Cosa Corp., 647 F. Supp. 600 (M.D. Tenn. 1986). In justification of its decision to grant a protective order to the West German corporate defendant in a contract case, the court stated: "This is a purely private litigation; no national interests of the United States are at stake save the interests in efficient functioning of the courts and justice for the litigation." Id. at 616. Although SE'S Screw Machine Co. involved the operation of the Hague Evidence Convention rather than a West German blocking statute, West Germany's exercise of its option under the Convention to refuse requests for pre-trial production of documents had the same effect as imposition of an actual blocking statute. Id. at 617.

117. Volkswagenwerk Aktiengesellschaft v. Superior Ct., 123 Cal. App. 3d 840, 859-60, 176 Cal. Rptr. 874, 886 (1981). 
that it regarded its decision as an exercise of judicial self-restraint designed to serve important international goals. ${ }^{118}$

Canadian courts, unlike those of the United States, have openly acknowledged the crucial importance of the public law/private law distinction to the question of compelling production of documents whose disclosure is prohibited by foreign law. For example, in Frischke $v$. Royal Bank,119 the Ontario Court of Appeals determined that court-ordered disclosure of information from bank officers in Panama would constitute a breach of Panamanian law. The court declined to require production in the absence of a showing of significant Canadian interests that would be furthered by production. ${ }^{120}$ In unequivocal language, the court acknowledged that such significant interests had never been found to be present in cases between private interests. ${ }^{121}$ The essential difference between the Canadian and United States approaches, therefore, is that the rhetoric of Canadian courts conforms to the substance of their decisions, while most U.S. courts outwardly claim to engage in comparative interest balancing but in fact base their determination on the presence or absence of a de minimis U.S. interest. In specifically rejecting an assessment and balancing of foreign interests, and requiring instead a straightforward determination of whether the case involves public or private law, the proposed formulation adheres to the approach explicitly recognized by the Canadian courts and implicitly employed by their U.S. counterparts.

\section{Actual Barriers and Good Faith}

Under the proposed analysis, production should be ordered once a court in a public law case is satisfied that the information requested is directly relevant, material, and necessary to the resolution of the case. On the other hand, in a case involving purely private civil law, the court must further determine whether sufficient good faith on the part of the party has been shown and whether the blocking statute presents an actual barrier to disclosure. The requirement of good faith involves two independent prongs of analysis. The first prong requires a showing that the requested party has not relied upon an unjustified or overbroad assertion of the scope and applicability of the blocking statute, and that reasonable affirmative efforts to comply with the discovery request were unsuccessful. The second prong requires a finding that the requested party did not purposefully court the foreign legal impediments which now block production.

The first prong of the good faith analysis focuses on whether, under the circumstances of the particular case, the blocking statute does in fact constitute an actual barrier to production. There are several different types of foreign blocking statutes. For purposes of analysis, it is possible to divide the

118. 123 Cal. App. 3d at 859, 176 Cal. Rptr. at 885 .

119. 17 Ont.2d 388 (1977).

120. Id. at 399.

121. Id. at 400 . 
many different blocking statutes into three categories based on the extent to which they present an actual barrier to production. Those statutes in the first category present an absolute barrier to production and are exemplified by the French blocking statute ${ }^{122}$ which is self-executing, covers all types of information requested by a foreign court, is subject to no exceptions, and cannot be waived. ${ }^{123}$ The South African Protection of Business Act, ${ }^{124}$ which is also self-executing but subject to waiver, is typical of those statutes which constitute a probable barrier to production. ${ }^{125}$ Blocking statutes such as those of Quebec and Ontario ${ }^{126}$ only present a possible barrier to production because they are not self-executing and instead apply only when provincial authorities declare them to be applicable.

Because the good faith requirement rests on a determination that the blocking statute actually prohibits the requested production, the "air-tight" statutes of the first category which prohibit even a request for (as well as disclosure of) information ${ }^{127}$ make further inquiry unnecessary. Cases involving the second type of statute require an additional showing that the requested party was unsuccessful in its efforts to secure permission from the foreign authorities to make the information available. ${ }^{128}$ Statutes of the third category involve a more complex inquiry. Bad faith is found when a party opposing discovery makes unsupported assertions regarding the applicability of the foreign-law prohibitions. ${ }^{129}$ As the following analysis of cases involving the Quebec and Ontario blocking statutes illustrates, courts require the requested party to bear the burden of proving both an inability to comply and government objections to compliance.

Few other nations' blocking statutes have received as much recent judicial scrutiny as Quebec's Business Control Records Act (Quebec Act) ${ }^{130}$ and its nearly identical counterpart, the Ontario Business Records Protection Act

122. See Law No. 80-538, [1980] J.O. 1799, reprinted in Note, Current Developments: The 1980 French Law on Documents and Information, 75 AM. J. INT'L L. 382, 383 (1981).

123. For a discussion of the French blocking statute, see id. at 382-86.

124. The text of the Protection of Business Act is reproduced in A. Lowe, Extraterritorial Jurisdiction: An Annotated Collection of Legal Materials 132-34 (1983).

125. Id. In the case of In re Uranium Antitrust Litig., 480 F. Supp. 1138,1155 (N.D. Ill. 1979), the South African Minister of Economic Affairs granted the plaintiff permission, pursuant to an exception contained in the Protection of Business Act, to inspect the requested documents as long as the documents did not leave South Africa.

126. Quebec Act, supra note 2; Ontario Business Records Protection Act, Ont. Rev. STAt. ch. 56, $\S 1-5$ (1980) [hereinafter Ontario Act].

127. Brewster, supra note 70 , at 68 .

128. In a case involving the Canadian Uranium Information Security Regulations, SOR, 76-644 (P.C. 1976-2368, Sept. 21 , 1976), promulgated under the authority of Canada's Atomic Energy Control Act, R.S.C. 1970, c. A-19, the court found that the party's diligent effort to secure a waiver from Canadian authorities was sufficient to constitute the required showing of good faith. In re Westinghouse Elec. Corp. Uranium Contracts Litig., 563 F.2d 992 (10th Cir. 1977).

129. See, e.g., Ohio v. Arthur Andersen \& Co., 570 F.2d 1370, 1373 (10th Cir.), cert. denied, 439 U.S. 833 (1978) (This case held that Andersen's unsubstantiated assertions that the Swiss law precluded discovery-without an investigation of the context of the requested documents to confirm that they were within the scope of the Swiss law-" "places in substantial doubt the credibility . . of Andersen's own insistence that it had 'proceeded in good faith to do the best it can'.").

130. Quebec Act, supra note 2. 
(Ontario Act). ${ }^{131}$ The Quebec Act prohibits the removal of any business information from Quebec pursuant to an order of a foreign court unless such removal is part of a regular reporting practice by a subsidiary to a foreign parent. ${ }^{132}$ The Quebec Act is not self-executing, but rather subjects a person or company to criminal sanctions for the production of such documents only after the Attorney General or a person having an interest in a concern has filed an application in a provincial court to prevent the imminent removal of business records from Quebec. ${ }^{133}$ Although the Quebec Act is worded broadly to prohibit the removal of documents from Quebec both before and after an application is filed in a provincial court, criminal penalties are prescribed only for acts occurring after the application. ${ }^{134}$ In cases in which no applications had been filed in a provincial court, United States courts have uniformly concluded that the Quebec Act and Ontario Act do not constitute an actual barrier and consequently that production should be ordered. ${ }^{135}$ In a recent case in which an application was filed and the provincial court ordered the party not to remove documents from Quebec or testify about their contents, the U.S. court found that the Quebec Act did in fact constitute a sufficient barrier and therefore refrained from ordering production of the requested documents. ${ }^{136}$

The second prong of the good faith requirement recognizes that a showing of affirmative efforts to overcome the blocking statute is by itself insufficient. The requested party's conduct prior to the imposition of the barrier must also meet the good faith standard. Courts have uniformly ordered production upon a finding that the party earlier courted the impediments it now unsuccessfully seeks to have waived. Under the principle of courting legal impediments, lack of good faith may be predicated on either a finding that the foreign entity (subsidiary or branch) which possesses the requested information was artificially created solely for the purpose of sequestering documents, or a finding that the requested party placed the

131. Ontario Act, supra note 126.

132. Quebec Act, supra note 2, §§ 1-2.

133. Quebec Act, supra note 2, $\S 4$. An attorney representing an officer or shareholder of the Canadian subsidiary can trigger enforcement of the blocking statute by making an application to the Quebec Provincial Court informing it that a United States court has requested production of business records in a manner prohibited by the Quebec Act. Telephone interview with Jean Yves Bernard, Office of the Attorney-General of Quebec (July 21, 1986).

134. Quebec Act, supra note 2, § 5.

135. See General Atomic Co. v. Exxon Nuclear Co., 90 F.R.D. 290, 294 (S.D. Cal. 1981) (Ontario Act); Petruska v. Johns-Manville, 83 F.R.D. 32, 37 (E.D. Pa. 1979) (Quebec Act); In re Uranium Antitrust Litig., 480 F. Supp. 1138, 1143 (N.D. Ill. 1979) (Ontario Act). Although these cases correctly hold that the Quebec and Ontario Acts are not an actual barrier to production until an application is filed in a provincial court, they erroneously state that criminal sanctions will not be issued for removing records from Canada unless the provincial court orders such a prohibition in response to an application of the Attorney General. In actuality, the Acts provide that imprisonment for violating the nondisclosure provisions may be imposed once an application is filed in a provincial court whether or not the court formally orders the furnishing of a security to ensure compliance. Quebec Act, supra note 2, § 5; Ontario Act, supra note 126, § 2(1)-(2).

136. State v. Keene Corp., No. 1 108600, slip op. (Cir. Ct. Md. July 10, 1986) (granting protective order). 
documents in the foreign country with knowledge that the nondisclosure law might frustrate discovery in possible future litigation. ${ }^{137}$

Certain limits to the principle of courting legal impediments must be recognized. For example, when documents originated in the foreign country and involve sensitive commercial information which is subject to greater safeguards of confidentiality under the foreign state's laws, it should not be considered bad faith to keep the documents in that country. Additionally, informing the foreign authorities of a request for documents that might contravene the state's nondisclosure laws should not be considered a bad faith courting of impediments even when the state responds by reinforcing the application of the blocking statute by issuing an order specifically compelling noncompliance with the U.S. discovery request. This limit is warranted because some foreign blocking statutes actually obligate companies to report any foreign discovery requests. ${ }^{138}$ Even the United States imposes such an obligation on U.S. subsidiaries of foreign enterprises that are asked to produce information sought to enforce the Arab League boycott of Israel. ${ }^{139}$

\section{IV}

\section{ConClusion}

In an early case involving extraterritorial discovery of documents whose disclosure was prohibited by a blocking statute, the court confidently declared that "mechanical or overbroad rules of thumb are of little value; what is required is a careful balancing of the interests involved." 140 This note has illustrated, however, that the absence of such concrete rules has led only to judicial confusion. Extraterritorial discovery law has suffered from a lack of coherence and predictability which can be imposed only through the adoption of a conceptual structure and guiding rules. In spite of stubborn judicial adherence to the rhetoric of comparative interest balancing, such rules are slowly emerging. Yet these rules have, until now, remained largely obscured by the verbiage of comparative interest balancing. This note has looked past form to substance, and has distilled from the case law a new framework which should ease the burdens and clear the confusion of extraterritorial decisionmaking confronting attorneys and judges. The most important aspect of this new approach is the explicit recognition that interest analysis in extraterritorial discovery cases should be unilateral rather than comparative, and should be based on a distinction between cases involving public and private law.

137. See United Nuclear Corp. v. General Atomic Co., 96 N.M. 155, 233, 629 P.2d 231, 309 (1980), cert. denied, 451 U.S. 901 (1981).

138. See, e.g., Law No. 80-538, 1980 J.O. 1799 (French blocking statute).

139. Export Administration Act of 1979, § 8, 50 U.S.C. $\S 2407$ (1982).

140. United States v. First Nat'l Bank, 396 F.2d 897, 901 (2d Cir. 1968). 
